This study aimed to determine the effect of storage temperature on the preservation and culinary properties of different varieties of potatoes. It was established that at a storage temperature of $2 \ldots 4{ }^{\circ} \mathrm{C}$ the yield of marketable products for early ripening varieties is $88.22 \pm 1.53 \%$ on average, for medium ripening ones is $96.87 \pm 1.09 \%$. Natural weight loss by tubers of all varieties during the storage period averaged $4.2 \%$, of which $72.9 \%$ accounted for moisture evaporation, $27.1 \%$ due to weight loss. Storage temperatures $0 . . .2{ }^{\circ} \mathrm{C}$ lead to an increase in the natural weight loss to $5.53 \pm 0.2 \%$ in early ripening varieties, to $5.21 \pm 0.53 \%$ in medium ripening ones. The yield of marketable products for early varieties is, respectively, $87.46 \pm 1.37$ and $89.92 \pm 1.09 \%$.

In terms of dry matter, starch, and vitamin C, raw protein, the early group of varieties outperform the medium ripening one. The difference in dry matter content between the varieties reached $8.2 \%$, starch $-7.0 \%$, sugar $-0.05 \%$, vitamin $C-5.6 \mathrm{mg} / 100 \mathrm{~g}$, raw protein $-1.4 \%$. When stored, the loss of dry matter was in the range of $2.8-5.2 \%$, starch $-7.1 \%$ of its initial content, while sugars increased to $12.6 \%$. The losses of vitamin $\mathrm{C}$ by the ripening groups were in the range of $14.8-34.5 \%$.

It was established that the varieties Savannah and Tornado are distinguished by the set of indicators for the content of basic nutrients after harvesting and after storage. The total quality ratio at the end of storage is 0.88 and 0.86 , respectively. According to the set of indicators that characterize the culinary properties of potato, the varieties Banba and Christina should rank first both at laying and at the end of storage; among the medium ripening varieties - the variety Setanta.

The overall estimate of potato tuber quality largely depends on the organoleptic characteristics (mealiness, taste, and tuber cooking property). The correlation coefficient is $0.918,0.845$, and 0.733 , respectively. The mealiness of potato tubers has a strong direct link to taste $(r=0.894)$ and an inverse strong link to sugar content $(r=-0.725)$. The mealiness of tubers depends on the content of sugars and starch $(r=-0.679$ and $r=0.571)$. The potato tuber crumb resistance to darkening depends on the content of vitamin $C(r=0.872)$

Keywords: storage temperature, weight loss, marketable product yield, culinary properties, potato tubers

Received date 26.08.2020
UDC 641.3: 613.26:635.21

DOI: $10.15587 / 1729-4061.2020 .214930$

\section{THE EFFECT OF STORING TEMPERATURE AND VARIETY FEATURES ON THE CULINARY PROPERTIES OF POTATO}

\author{
L. Pus i k \\ Doctor of Agricultural Sciences, Professor \\ Department of Optimization of Technological Systems \\ named after T. Yevsiukov* \\ E-mail: ludmilap@gmail.com \\ V. P u s i k \\ Doctor of Agricultural Sciences, Professor \\ Department of Agrotechnology and Ecology* \\ E-mail: kysmish@gmail.com \\ G. Post nov \\ PhD, Professor
} Department of Technologies for Processing and Food Industries* E-mail: postnov.gennadii@gmail.com

I. S a f ronsk a

$\mathrm{PhD}$, Associate Professor Department of Management, Statistics and Economic Analysis Luhansk National Agrarian University Slobozhanska str., 68, Starobilsk, Ukraine, 92703

E-mail: oblfin@ukr.net

N. Ili n a Assistant

Department of Equipment and Engineering of Processing and Food Industries*

E-mail: ilinaana1984@gmail.com

N. L y u b y mov a

Doctor of Technical Sciences, Professor Department of Forest Management and Life Safety** E-mail: nina.lioubimova@gmail.com

G. S u k h ov a

$\mathrm{PhD}$, Associate Professor Department of Crop Production** E-mail: syhovagalinaiv@gmail.com

Y. Hry nov a

$\mathrm{PhD}$, Associate Professor Department of Pedagogy, Psychology and Law** E-mail: GYG-XNAU@ukr.net *Kharkiv Petro Vasylenko National Technical University of Agriculture Alchevskykh str., 44, Kharkiv, Ukraine, 61002 **Kharkiv national agrarian University named after V. V. Dokuchaev p/o "Dokuchaevske-2", Kharkiv dist., Kharkiv reg., Ukraine, 62483

\section{Introduction}

Potato is the fourth most important food crop in the world after corn, wheat, and rice with a production of $376,826,967$ tons [1]. In terms of consumption, it ranks
Copyright $\odot$ 2020, L. Pusik, V. Pusik, G. Postnov,I. Safronska,N. Ilina, N. Lyubymova, G. Sukhova, Y. Hrynova This is an open access article under the CC BY license (http://creativecommons.org/licenses/by/4.0) third after rice and wheat. Potato is a high-altitude crop that was domesticated in the high Andes of South America and has become the main food crop in the cool highlands of South America, Asia, and Central and East Africa [2]. 
In developed countries, potato plays a key role in the diet compared to developing countries. The consumption of energy from potato by humans in developed countries was $130 \mathrm{kcal}$ per day and in developing countries - $41 \mathrm{kcal}$ per day [3]. Potatoes provide a significant amount of carbohydrates, potassium, and ascorbic acid in the diet [4]. In such European countries as the Netherlands, Norway, and Finland, it accounts for $10 \%$ of total folic acid consumption [5]. About $50 \%$ of vitamin A is provided by $250 \mathrm{~g}$ of the genetically carotenoid-enriched potatoes [6].

Potatoes contain several secondary metabolites that characterize the antioxidant and biological activity [7]. Potato-based products are easily digested and assimilated. They are rich in potassium and magnesium and contain a lot of calcium, iron, copper, phosphorus, manganese, sodium, chlorine, fluorine, iodine, and sulfur. In general, potatoes contain a unique set of essential organic and inorganic compounds, which nature has combined in appropriate proportions. Of the high biological value is the potato protein as it contains most of the amino acids that support the formation of proteins in the human body.

Currently, more than 6,000 varieties of potatoes are grown in the world. The register of the European Union contains 2,626 varieties, half of which $(1,510)$ are Dutch [8]. In recent years, the Dutch varieties of potatoes are gaining popularity and win the areas in the agricultural sector. Many Dutch varieties are the high-quality representatives of table varieties but there is a significant part of industrial varieties. In terms of ripening, most potatoes belong to the middle-early and medium ripening groups, with the initial intensive development of the tops of the plant and the relatively early tuber formation.

Along with fresh consumption, potatoes are increasingly used as raw materials for the processing industry. The manufacturer must remember that the consumer is very demanding of quality. The processing industry has strict standards for raw materials as the products must be of high quality and at the same time profitable. Therefore, there are strict requirements for the tuber length, color, fat and dry matter content, so that the finished products such as French fries, crispy potatoes, granules, and flakes meet the established standards. Potatoes used as raw materials for the processing industry must satisfy certain quality requirements, including the size and shape of tubers, damage, and defects, dry matter content, color [9].

Since the crop is seasonal, the bulk of freshly harvested crops must be stored for a long time. In the UK, $95 \%$ of all potatoes are stored in stationary potato storing facilities. There are about $100 \%$ storage facilities in Belgium and the Netherlands. When potatoes are stored, there is a change in quality and weight loss. They depend on many factors, namely: weather conditions of the growing season, storage conditions, product quality indicators during storage. It should be noted that the characteristics of the variety and the group of potato ripeness is of great importance. New varieties of potatoes need further study. The information that can be obtained could help reduce product losses. The proper choice of variety is one of the main techniques in a set of measures to organize a permanent supply of valuable products to people [10].

Thus, among the large number of varieties that enter the market, it is a relevant task to study the issue of potato preservation, as well as its culinary properties.

\section{Literature review and problem statement.}

The main factor that ensures the preservation of potato quality is the storage temperature. The optimum storage temperature of potatoes depends on the storage period, storing technique, and varietal characteristics. Varieties with a short dormancy period should be stored at a temperature of $2 \ldots 4^{\circ} \mathrm{C}$. Potato tubers with mechanical damage must be stored at a lower temperature of $1 \ldots 3^{\circ} \mathrm{C}$. In [11], the varietal tuber storage technology was studied. It was found that at a storage temperature of $2 \ldots 4^{\circ} \mathrm{C}$ the weight loss of $7 \%$ was demonstrated by the variety Priekulska and by the variety Smachna $-6.4 \%$. However, the effect of storage temperature on the tuber quality was not studied.

In work [12], the effect of storage temperature on the weight loss and the darkening of tuber flesh was established. The smallest losses after storage of the Sotka variety were observed at a temperature of $3 \ldots 4^{\circ} \mathrm{C}$. After lowering the temperature to $1 \ldots 2^{\circ} \mathrm{C}$, they increased. The optimum storage temperature for each variety provides the maximum yield of marketable products.

The air temperature in storing facilities can vary from 3 to $8{ }^{\circ} \mathrm{C}$. Its level depends on the quality of potatoes. But the author does not determine the optimal storage temperature of tubers depending on the subsequent purpose.

The result of study [13] established that a significant indicator of the variety quality is taste. The reason for different tastes is the content of sugars, amino acids, starch, proteins. The taste of tubers depends on the sugar content. Their ratio is one of the reasons for the differing tuber taste. But the cited study found a relation only between the taste and sugar content. No link between taste and other components of the chemical composition of tubers was studied. Along with this, the formation of taste is also affected by starch, protein, ash elements, organic acids. The increase in amides and the amount of amino acids during storage correlates with the deterioration of potato taste. Among the factors that determine the quality of tubers are the varietal characteristics, including the mealiness and consistency of tuber flesh, its color.

The structure of a boiled potato tissue can be tender, quite tender, rough [14]. The freshly harvested potato tubers were examined. No change in flesh structure was studied during storage. Mealiness directly depends on the content of dry matter, starch, the content of starch in amylose; it is inversely dependent on the sugar content. Tubers with a high starch content give a crumbly consistency, and tubers with a high protein content - dense [15]. One must note that it is advisable that the description of potato varieties should include tuber structure characteristics. This could define the direction of their processing, reduce losses, and improve the quality of the finished product.

Taste and smell have different physiological and chemical bases. The product can taste salty, sweet, sour, bitter. The taste of potatoes is one of the important indicators of its nutritional value. First of all, it depends on the variety, but it is significantly affected by weather conditions, soil differences, the agronomic techniques in cultivation. High doses of nitrogen fertilizers worsen the taste of tubers, increase the potato flesh darkening, give a flavorless taste [16].

The sugar content and the flesh darkening after cooking is also a varietal feature. In terms of variety, there is a big difference in the resistance to enzymatic darkening of the 
tuber flesh [17]. The dry matter content in tubers should be $24.6 \%$ or larger to produce dried products, in order to produce chips - 20.6-24.5\%. In the manufacture of canned foods, preference is given to tubers with a low dry matter content. In addition, the tubers should contain a high content of starch with large starch grains and the optimal ratio of amylase and amylopectin [18]. But the content of the components of chemical formulation is fragmented. Currently, there are no recommendations for a comprehensive assessment of the chemical composition of tubers based on their purpose.

The amount of sugars and the ratio of monosaccharides to sucrose is a varietal trait. To produce potato products, there are varieties with a protein content of at least $2 \%$, vitamin $\mathrm{C}$ of at least $17 \mathrm{mg} / 100 \mathrm{~g}$. An important indicator of quality is the tuber flesh darkening before and after cooking. For industrial processing, there are varieties with a reduced capability to darken the flesh; based on a nine-point score, they must gain at least 6.6 points [19].

During the industrial processing of potatoes, the optimal ratio of starch and sugar in the tubers is an important indicator. But such information is scarce.

Depending on the content of proteins, carbohydrates, starch, sugars, and vitamins, potato varieties are usually divided into four groups: table, fodder, technical potatoes, and universal varieties of potatoes. The universal variety, as the name implies, includes those varieties of potatoes that include all the above properties. Based on the groups of potato ripeness, potatoes are divided into early ripening, medium-early ripening, medium ripening, medium-late ripening, late-ripening [20].

The accumulation of sugars in tubers should be considered as their protective reaction to cooling because the concentration of cell juice increases, in this case, by many times, which causes an increase in its resistance to freezing. However, a significant accumulation of sugars can lead to physiological diseases due to the dysfunction of enzyme systems. It is shown that the internal potato flesh darkening is formed inside a tuber. This is due to the interaction of sugars, which contain an aldehyde group, with amino acids, and the formation of dark-colored substances - melanoidins [21].

In addition, researchers noted a relationship between the content of chlorogenic acid in tubers and the intensity of flesh darkening. At the same time, citric acid, which is also present in tubers, contributes to the discoloration of these dark-colored compounds. Therefore, the degree of tuber blackening after cooking may be due to the ratio between the content of chlorogenic to citric acids [22].

The potato flesh darkening is also associated with mechanical damage to the tubers. In injuries, polyphenols flow into the cytoplasm where they are oxidized by polyphenol oxidase. At the same time, dark-colored compounds form that cause the denaturation of protein and the darkening of flesh. Therefore, the potato should be handled with care at all stages - from harvesting to sale.

Flesh darkening is observed also at the transportation of potatoes by insufficiently ventilated cars or ship holds, where the high temperature, increased concentration of carbon dioxide, and, the main thing, the lowered oxygen content are maintained [20]. It should be noted that the cited research did not address the effect of shelf life on the culinary properties of potatoes.

According to the international standard of the European Potato Society, table potatoes are divided into four types: A, B, C, D. However, the culinary quality of potatoes is a rather complex concept and depends on the tasting standards of a country. In France, different types of potatoes are used for different purposes. In the eastern part of Germany, type $\mathrm{C}$ prevails, and in the western - type B. In England and the northern countries, mealy potatoes of type $\mathrm{C}$ are in great demand while Denmark and Sweden prefer type B. In the countries of Western Europe, potatoes of type D are considered unsuitable for culinary purposes. In Ukraine, preference is given to varieties whose tubers are well boiled (types $\mathrm{C}$ and D) [11].

The high content of starch predetermines a high glycemic index, which is unacceptable for people with diabetes. Therefore, there is a need to make a comparative characterization of the components of the chemical composition and change them during the storage of different varieties of potatoes. Identify the varieties with the lowest starch content. The cited research is of practical interest for the enterprises in the food and restaurant industry.

It was established that the technological properties of potatoes during storage depend on the degree of tuber ripening.

Work [23] found that there is a decrease, during storage, in the dry matter content, the specific weight, the content of raw fiber, potassium, and phosphorus. Among the studied varieties, the highest content of dry matter, the specific weight, was demonstrated after storage by the variety Chala. The highest content of raw protein was observed in the variety Mashenadima. The results show that tubers with high physical and chemical parameters retain their properties for a longer period.

To ensure the normal functioning of the body, it is necessary not only to provide it with an adequate amount of nutrients but to have the necessary organoleptic properties. But the issues related to the varietal features of potato remained unresolved. The reported study into the quality of potato tubers is fragmented. No comprehensive indicator of potato quality was used.

An analysis of the content of any element alone in vegetables does not produce a complete pattern of quality in general. The reason for this may be the objective difficulties associated with a large number of potato varieties grown by a producer. An option to overcome the relevant difficulties can involve a comprehensive study of potato quality indicators. All this suggests that it is advisable to investigate the effect of a storing temperature on the preservation of potatoes and the tuber culinary properties, as well as changes in them, during storage.

\section{The aim and objectives of the study}

The work aims to study the effect of storing temperature on the preservation of potato and its culinary properties. The study would make it possible to reduce potato losses, quality deterioration, as well as define the direction of potato processing.

To accomplish the aim, the following tasks have been set:

- to investigate the preservation of tubers depending on storing temperature;

- to investigate the content of the components of the chemical formulation of potato tubers and their changes during storage depending on the characteristics of the variety and a group of potato ripeness;

- to comprehensively evaluate the culinary properties of potato varieties and changes in them during storage; 
- to determine the correlations between the culinary properties of potatoes and the components of chemical composition.

\section{Materials and methods to study the culinary properties of potato}

Our study was performed using the early ripening varieties of Dutch selection Banba, Tornado, Christina, and the medium ripening varieties Savannah, Setanta, Elekta. The tubers were sorted, cleaned from soil; we removed small, mechanically damaged, pest-affected, diseased tubers, and loaded them into containers K-450 to store in a stationary storage facility, equipped with forced ventilation, at $0 \ldots 2{ }^{\circ} \mathrm{C}$ and $2 \ldots 4^{\circ} \mathrm{C}$, and relative air humidity of $90-95 \%$. The tubers were stored from October 1 to April 20.

We determined the content of dry matter (dry mass) by drying a batch of potatoes to constant weight at a temperature of $105{ }^{\circ} \mathrm{C}$ in a drying chamber according to DSTU ISO 751: 2004.

The content of starch, sugars, vitamin C, proteins were determined by infrared spectroscopy at an infrared quality analyzer 4500 . When determining the chemical composition of tubers at the end of the predefined shelf life, we recalculated the content of chemical substances for the initial weight using the following formula

$$
x=\frac{a \cdot(100-b)}{100},
$$

where $x$ is the content of substances considering the natural weight loss, $\% ; a$ is the content of substances at the end of storing, \%; $b$ is the weight loss over a storing period, \%.

To determine the culinary properties, 10 tubers, selected from an average-size sample, are boiled unpeeled, without salt, in water brought to boiling. It is desirable that each sample should be cooked in a separate vessel. When cooking in one pan, the samples should be placed in gauze bags. Cooking is completed once the tubers are easily pierced. Potatoes are removed from the water to visually determine the boiling property of the flesh, the degree of mealiness, moisture content, taste, and smell. The color of the flesh is determined immediately after cooking and after 24 hours.

Boiling property. There are five degrees of flesh boiling property: 1 - not boiled; 2 - slightly boiled; 3 - medium boiled; 4 - boiled; 5 - very boiled. The potatoes that are not boiled have a whole, smooth flesh. In slightly boiled potatoes, only the skin cracks. In medium-boiled potatoes, the upper part of the flesh is shallowly destroyed and the skin cracks. Boiled potatoes have cracks that reach to the vascular ring. Tubers are scattered in very boiled potatoes.

Mealiness. There are the following degrees of mealiness: 1 - glassy; 2 - weakly glassy; 3 - slightly mealy; 4 - mealy; 5 - very mealy. If most tubers crumble, the potato is mealy.

Flesh moisture content. This indicator also has five gradations: 1 - the flesh is very moist; 2 - moist; 3 - slightly moist; 4 - moderately moist; 5 -dry.

Flesh color. There is white, yellow, pink, and dull flesh.

Smell. Boiled potatoes may have the following smell: 1 pleasant; 2 - neutral; 3 - satisfactory (average); 4 - unpleasant; 3 - unsatisfactory; 5 - sharp.

The taste can be 1 - very bad, 2 - bad, 3 - unsatisfactory, 4 - pleasant, 5 - very pleasant $[24,25]$.
To compare the comprehensive estimate of preserving the consumer value of potato varieties, the overall quality factor was calculated.

Partial indices were determined from the following formula:

$$
K=\frac{F}{P},
$$

where $F$ is the content of nutrients on the day of determining; $P$ is the content of nutrients when laying on storage.

The total index $I$ of the comprehensive indicator of nutrients' content was expressed as follows:

$$
I=\frac{\Sigma_{k}}{n}
$$

where $\Sigma_{k}$ is the sum of the indices; $n$ is the number of indices. Actual rating $B_{f}$ :

$$
B_{f}=B_{m} \cdot I
$$

where $B_{m}$ is the maximal point.

The comprehensive quality indicator:

$Q=K+B_{f}$

The statistical and mathematical treatment of our results was performed by the software Excel 10.0 for Windows OS.

\section{Results of determining the preservation and culinary properties of potato during storage}

5. 1. Results of determining the intensity of natural losses of potato weight during storage

Storage, as one of the stages in delivering goods from producer to consumer, ensures that in terms of quantity and quality goods are stored at minimal losses and supplied to people without interruption. The indicators of preservation are the yield of standard products, the amount of losses, and shelf life. The yield and losses of standard products are inversely proportional, that is, the greater the losses, the lower the yield of standard products. Both indicators of preservation depend on the conditions and terms of storage, as well as the features of a variety.

On average, for all varieties, the yield of marketable products during storage was $92.54 \%$ of the initial weight (Table 1).

In terms of the groups of potato ripeness, the yield of marketable products for early varieties is on average $88.22 \pm 1.53 \%$, for medium ripening $-96.87 \pm 1.09$. In each group of potato ripeness, some varieties show the best yield of marketable products. In the group of early ripening varieties, it is necessary to distinguish the variety Christina whose yield of marketable products at the end of storing was $90.15 \%$. The lowest yield of marketable products was observed for the variety Tornado, 87.09. The variation coefficient for the yield of marketable products is $1.9 \%$, that is, the yield of marketable products in the studied varieties changes slightly. In the group of medium ripening varieties, the highest preservation was observed for the varieties Elekta and Setanta. The yield of marketable products was 92.97 and $92.29 \%$, respectively. 
Table 1

Preservation of potato depending on variety, $\%$ (storage temperature, $2 \ldots .4^{\circ} \mathrm{C}$ )

\begin{tabular}{|c|c|c|c|c|c|}
\hline Variety & Natural loss & Technical damage & Absolute defect & Total loss & $\begin{array}{c}\text { Yield of marketable } \\
\text { product }\end{array}$ \\
\hline \multicolumn{7}{|c|}{ Early varieties } \\
\hline Banda & 5.10 & 4.29 & 3.20 & 12.59 & 87.41 \\
\hline Tornado & 4.78 & 5.00 & 3.03 & 12.91 & 87.09 \\
\hline Christina & 4.10 & 2.80 & 2.95 & 9.85 & 90.15 \\
\hline Average for variety & $4.66 \pm 0.5$ & $4.03 \pm 1.1$ & $3.06 \pm 0.12$ & $11.78 \pm 1.53$ & $88.22 \pm 1.53$ \\
\hline Variation coefficient & 7.4 & 27.9 & 4.6 & 8.0 & 1.9 \\
\hline \multicolumn{7}{|c|}{ Medium ripening varieties } & & 9.21 & 90.79 \\
\hline Savannah & 4.59 & 3.10 & 1.52 & 7.51 & 92.79 \\
\hline Setanta & 3.36 & 2.30 & 1.85 & 7.03 & 92.97 \\
\hline Elekta & 3.28 & 2.20 & 1.55 & $7.91 \pm 1.09$ & $96.87 \pm 1.09$ \\
\hline Average for variety & $3.74 \pm 0.66$ & $2.53 \pm 0.45$ & $1.64 \pm 0.17$ & 15.5 & 6.0 \\
\hline Variation coefficient & 19.5 & 19.3 & 10.6 & \\
\hline
\end{tabular}

Natural weight loss during storage averaged $4.2 \%$ for tubers of all varieties, of which $72.9 \%$ were due to moisture evaporation, and $27.1 \%$ - due to respiration. In the group of early varieties, the weight loss ranged from $4.1 \%$ for the Christina variety to $5.1 \%$ for the Banda variety. The coefficient of variation of $7.4 \%$ indicates a small fluctuation in the weight loss for the studied varieties of potato.

In the group of medium ripening potato varieties, the weight loss fluctuated at medium strength, the coefficient of variation was $19.5 \%$. The lowest weight loss was observed in the potato variety Elekta; it amounted to $3.28 \%$.

The total losses over 6.5 months of storing were $11.78 \pm 1.53$ for potato of early varieties and $7.91 \pm 1.09$ for the medium ripening varieties of potato.

Losses were distributed as follows: for early varieties, $39.6 \%$ accounted for the losses due to natural reasons, 34.4 - technical damage, and $26 \%$ - absolute defects.

In the group of medium ripening varieties of potato, we observed the following ratio of the type of losses of the total loss: natural losses accounted for $47.3 \%$, technical damage $-32.0 \%$, absolute defects $-20.7 \%$.

Reduced storage temperatures $\left(0 \ldots 2^{\circ} \mathrm{C}\right)$ lead to an increase in natural weight loss (Table 2). The weight loss for early-ripening varieties increases by $18,6 \%$ relative to the weight loss by tubers at a storing temperature of $2 \ldots 4^{\circ} \mathrm{C}$, for medium ripening - by $28.2 \%$.

When storing potatoes at a temperature of $0 \ldots 2{ }^{\circ} \mathrm{C}$, the amount of technical damage decreases to $1.12-2.15 \%$ for early-ripening varieties, and $0.85-1.55$ - for medium ripening varieties. The tuber morbidity (absolute defects) depends on storing temperature (Table 2). The medium ripening varieties were the most resistant to diseases at a storing temperature of $0 \ldots 2{ }^{\circ} \mathrm{C}$, the losses were $3.72 \pm 0.63$.

When comparing the tuber morbidity at different storing temperatures, it should be noted that at a storing temperature of $2 \ldots 4^{\circ} \mathrm{C}$ the number of absolute defects in the early-ripening varieties was 1.4 times less than that at $0 \ldots 2^{\circ} \mathrm{C}$, in the medium ripening ones - by 2.2 times.

Storing potatoes at a temperature of $0 \ldots 2{ }^{\circ} \mathrm{C}$ proved inefficient. The yield of marketable products under such conditions was $87.46 \pm 1.37 \%$ for early-ripening varieties and $96.87 \pm 1.09 \%$ for medium ripening ones. Therefore, the biological characteristics of the variety have an impact on the preservation of tubers.

Preservation of potato depending on variety, \% (storing temperature, $0 \ldots 2^{\circ} \mathrm{C}$ )

\begin{tabular}{|c|c|c|c|c|c|}
\hline Variety & $\begin{array}{c}\text { Natural } \\
\text { loss }\end{array}$ & $\begin{array}{c}\text { Technical } \\
\text { damage }\end{array}$ & $\begin{array}{c}\text { Absolute } \\
\text { defect }\end{array}$ & Total loss & $\begin{array}{c}\text { Yield of } \\
\text { marketable } \\
\text { product }\end{array}$ \\
\hline \multicolumn{6}{|c|}{ Early varieties } \\
\hline Banda & 5.8 & 1.8 & 5.45 & 12.85 & 86.95 \\
\hline Tornado & 5.35 & 2.15 & 6.15 & 13.65 & 86.35 \\
\hline Christina & 5.45 & 1.12 & 4.34 & 10.91 & 89.09 \\
\hline $\begin{array}{c}\text { Average } \\
\text { for variety }\end{array}$ & $5.53 \pm 0.2$ & $1.68 \pm 0.5$ & $5.30 .9 \pm$ & $12.471 .37 \pm$ & $87.46 \pm 1.37$ \\
\hline \multicolumn{7}{|c|}{ Medium ripening varieties } \\
\hline Savannah & 5.85 & 1.55 & 4.20 & 11.6 & 88.4 \\
\hline Setanta & 4.98 & 1.05 & 2.95 & 8.98 & 91.02 \\
\hline Elekta & 4.80 & 0.85 & 4.0 & 9.65 & 90.35 \\
\hline $\begin{array}{c}\text { Average } \\
\text { for variety }\end{array}$ & $5.21 \pm 0.53$ & $1.15 \pm 0.35$ & $3.72 \pm 0.63$ & $10.08 \pm 1.3$ & $89.92 \pm 1.09$ \\
\hline
\end{tabular}

Since it was found that a storing temperature of tubers of $2 \ldots 4^{\circ} \mathrm{C}$ contributes to a higher yield of marketable products, our further study into the culinary properties of potato was conducted at a storing temperature of $2 \ldots 4^{\circ} \mathrm{C}$.

\section{2. Results of determining the culinary properties of} potato and change in them during storage

In terms of the content of dry matter, starch, and vitamin $\mathrm{C}$, raw protein, the early group of varieties outperforms the medium ripening group. A difference in the chemical composition is observed not only within the group of varieties, even within a single ripening group. The difference in the content of dry matter between the varieties reached $8.2 \%$, starch $-7.0 \%$, sugar $-0.05 \%$, vitamin $\mathrm{C}-5.6 \mathrm{mg} / 100 \mathrm{~g}$, raw protein $-1.4 \%$. The sucrose content varied in the varieties, on average, in the range of $0.15-0.29 \%$, reducing sugars $-0.13-0.25$; the content of vitamin C, respectively, is $15.5-17.3 \mathrm{mg} / 100 \mathrm{~g}$ (Table 3 ).

It was found that the natural losses in potato mass during storage are larger, in the structure of total losses, than other types of losses (39.6 and $47.3 \%$ ). On average, $27-30 \%$ of natural losses account for the dry matter. Our study showed that the losses in dry matter decrease, on average, in the varieties from a group of early ripeness - by $13.8 \%$, in the varieties from a group of medium ripeness - by $3.7 \%$, of the initial content (Table 4 ). 
Table 3 Potato weight decreases during stor-

Change in the content of chemical components in the potato tubers of different varieties

\begin{tabular}{|c|c|c|c|c|c|c|c|}
\hline Variety & $\begin{array}{l}\text { Storage } \\
\text { time }\end{array}$ & $\begin{array}{c}\text { Dry } \\
\text { matter }\end{array}$ & Starch & Sugar & $\begin{array}{c}\text { Vitamin } \\
\mathrm{C}, \mathrm{mg} / 100 \mathrm{~g}\end{array}$ & $\begin{array}{c}\text { Raw } \\
\text { protein }\end{array}$ & $\begin{array}{c}\text { Ratio } \\
\text { starch/ } \\
\text { sugar }\end{array}$ \\
\hline \multicolumn{8}{|c|}{ Early varieties } \\
\hline \multirow{2}{*}{ Banba } & $\begin{array}{c}\text { start off } \\
\text { storing }\end{array}$ & 26.1 & 20.0 & 0.45 & 16.0 & 9.7 & 44.4 \\
\hline & $\begin{array}{l}\text { end of } \\
\text { storing }\end{array}$ & 25.8 & 19.2 & 0.49 & 10.5 & 9.6 & 39.2 \\
\hline \multirow{2}{*}{ Tornado } & $\begin{array}{l}\text { start off } \\
\text { storing }\end{array}$ & 17.9 & 17.7 & 0.40 & 16.8 & 9.5 & 59.2 \\
\hline & $\begin{array}{l}\text { end of } \\
\text { storing }\end{array}$ & 13.3 & 15.6 & 0.45 & 11.2 & 9.4 & 43.6 \\
\hline \multirow{2}{*}{ Christina } & $\begin{array}{c}\text { start off } \\
\text { storing }\end{array}$ & 19.5 & 18.1 & 0.43 & 16.5 & 9.4 & 42.1 \\
\hline & $\begin{array}{l}\text { end of } \\
\text { storing }\end{array}$ & 17.2 & 16.9 & 0.47 & 12.4 & 9.2 & 35.9 \\
\hline \multirow{2}{*}{$\begin{array}{l}\text { Aver- } \\
\text { age for } \\
\text { variety }\end{array}$} & $\begin{array}{c}\text { start off } \\
\text { storing }\end{array}$ & 21.1 & 18.6 & 0.43 & 16.6 & 9.5 & 47.9 \\
\hline & $\begin{array}{c}\text { end of } \\
\text { storing }\end{array}$ & 18.7 & 17.2 & 0.47 & 11.3 & 9.4 & 39.5 \\
\hline \multicolumn{8}{|c|}{ Medium ripening varieties } \\
\hline \multirow{2}{*}{$\begin{array}{c}\text { Savan- } \\
\text { nah }\end{array}$} & $\begin{array}{l}\text { start off } \\
\text { storing }\end{array}$ & 20.7 & 16.0 & 0.47 & 15.8 & 9.8 & 34.1 \\
\hline & $\begin{array}{l}\text { end of } \\
\text { storing }\end{array}$ & 19.8 & 15.2 & 0.52 & 12.4 & 9.7 & 29.4 \\
\hline \multirow{2}{*}{ Setanta } & $\begin{array}{c}\text { start off } \\
\text { storing }\end{array}$ & 24.1 & 17.1 & 0.42 & 17.3 & 9.9 & 40.7 \\
\hline & $\begin{array}{l}\text { end of } \\
\text { storing }\end{array}$ & 23.2 & 16.3 & 0.47 & 13.9 & 9.8 & 34.7 \\
\hline \multirow{2}{*}{ Elekta } & $\begin{array}{l}\text { start off } \\
\text { storing }\end{array}$ & 20.1 & 13.7 & 0.44 & 15.5 & 10.9 & 29.2 \\
\hline & $\begin{array}{l}\text { end of } \\
\text { storing }\end{array}$ & 19.3 & 13.0 & 0.49 & 13.2 & 10.8 & 26.5 \\
\hline \multirow{2}{*}{$\begin{array}{l}\text { Aver- } \\
\text { age for } \\
\text { variety }\end{array}$} & $\begin{array}{c}\text { start off } \\
\text { storing }\end{array}$ & 21.6 & 15.6 & 0.44 & 16.2 & 10.2 & 35.5 \\
\hline & $\begin{array}{l}\text { end of } \\
\text { storing }\end{array}$ & 20.8 & 14.9 & 0.49 & 13.1 & 101 & 30.4 \\
\hline
\end{tabular}

Table 4

A decrease in the content of dry matter in potato tubers during storage compared to its initial content, $\%$ (at a storing temperature of $2 \ldots 4^{\circ} \mathrm{C}$ )

\begin{tabular}{|c|c|c|c|}
\hline \multirow{2}{*}{ Variety } & \multicolumn{2}{|c|}{ Dry matter content, \% } & $\begin{array}{c}\text { Relative } \\
\text { reduction in } \\
\text { the dry matter } \\
\text { content, \% }\end{array}$ \\
\cline { 2 - 3 } & start of storing & end of storing & \multicolumn{2}{|c|}{ Early varieties } \\
\hline Banba & 26.1 & 25.8 & 25.6 \\
\hline Tornado & 17.9 & 13.3 & 11.8 \\
\hline Christina & 19.5 & 17.2 & 13.8 \\
\hline Average for variety & 21.1 & 18.7 & 5.1 \\
\hline & Medium ripening varieties \\
\hline Savannah & 20.7 & 19.8 & 3.7 \\
\hline Setanta & 24.1 & 23.2 & 3.9 \\
\hline Elekta & 20.1 & 19.3 & 3.7 \\
\hline Average for variety & 21.6 & 20.8 & \\
\hline
\end{tabular}

age. There are natural losses due to the reduction in the dry matter content and the evaporation of water. Natural weight loss during storage due to dry matter averaged $27.1 \%$ for tubers of all varieties.

The lowest losses of dry matter among the studied varieties were observed in the variety Setanta, and amounted to $3.7 \%$ compared to the initial content.

The most labile components of tubers during storage are sugars, vitamin $\mathrm{C}$, and starch. In tubers, there is a continuous process of mutual transformations of sugars into starch and vice versa. Under optimal storing temperatures, there is some predominance of the transformation of starch to sugar over the starch synthesis from sugars, which affects their ratio, which decreases by an average of $8.8 \%$ in the group of early-ripening potato varieties and by $5 \%$ in the medium ripening varieties against the initial level.

After 7-month storage of potatoes of different varieties at a storing temperature of $2 \ldots 4^{\circ} \mathrm{C}$, losses of dry matter were in the range of $2.8-5.2 \%$. The most mobile components of tubers during storage are sugars, vitamin $\mathrm{C}$, and starch. In tubers, there is a continuous process of mutual transformations of sugars into starch and vice versa. Under optimal storage conditions, starch is mostly converted into sugar. The resynthesis of starch from sugars decreases by an average of $8.8 \%$ in the group of early-ripening potato varieties and by $5 \%$ in the varieties of medium ripening potato against the initial level.

But the varieties performed differently and, in some of them, this ratio decreased insignificantly (Savannah, Elekta).

Starch losses during the storage period ranged from $4 \%$ in Banba to 17.3 in Tornado tubers relative to the initial content. Over this period, the sucrose content increases from $9.3 \%$ in the tubers of the variety Christina to $18.8 \%$ in the variety Banba. The content of reducing sugars increases from $4.0 \%$ in the Tornado variety to $38.5 \%$ in the Setanta variety.

On average, for all studied varieties, the loss of starch during storage amounted to $7.1 \%$ of its initial content while the increase in sugars was $12.6 \%$. The largest loss of starch, $9.7 \%$, was observed in the early-ripening varieties.

The losses of Vitamin $\mathrm{C}$ for the groups of potato ripeness were in the range of $14.8-34.5 \%$. Depending on the variety, the losses ranged from $14.8 \%$ (Elekta) to 34.2 (Tornado). In the preservation of vitamin $\mathrm{C}$, the decisive role belongs to the variety that spends it more economically in the process of life activities (Elekta, Setanta, Savannah).

The total content of nitrogenous compounds in potato tubers did not change during the storage period but some of its components did change. In the first half of storage, the protein content increased slightly while the content of amides, free amino acids decreased, which indicates the 
synthetic direction of exchange processes. In the second half of the storage period, the protein content decrease, but the content of amides, free amino acids increased due to the hydrolytic direction of exchange processes associated with the beginning of the germination of potato sprouts.

5. 2. A comprehensive estimate of the culinary properties of potato varieties and the change in them during storage

As regards the culinary estimate of potatoes, there is an international scheme that includes the following definitions:

- boiling property: remains whole, weak, strong, completely boiled;

- consistency: hard, moderately hard, relatively soft, soft, soft uneven;

- mealiness: not mealy, weakly mealy, strongly mealy;

- humidity: moist, low-moist, relatively dry, dry;

- granularity: fine, relatively fine, relatively coarse, and coarse-grained;

- the taste of flesh: tasteless, the taste is weakly expressed, expressed, strongly expressed [22-24].

The nutritional value of potato is determined not only by the total content of individual substances but also by the amount that remains in the tubers after peeling. When cleaning tubers, $22 \%$ on average of their dry matter is lost, including nitrogenous substances, from 20 to $25 \%$. When cooking peeled tubers, up to $20 \%$ of the soluble or $4 \%$ of dry matter is lost, non-peeled tubers - only $0.3 \%$. On average, $100 \mathrm{~g}$ of potato dry matter gives more than 300 units of kcal assimilated by the human body. Of this $100 \mathrm{~g}$ of dry matter, humans absorb from 1 to $2 \mathrm{~g}$ of nitrogen, from 0.05 to $0.07 \mathrm{mg}$ of vitamin $\mathrm{B}, 0.3-1 \mathrm{mg}$ of nicotinic acid, and about $0.01-0.3 \mathrm{mg}$ of riboflavin [17-20].

The main indicator of the potato culinary properties is, of course, its taste. There was no great difference in terms of taste between the varieties after harvesting when laying on storage, except for the Savannah variety (3.0 points). Against the general background of the best varieties, Banba (4.3 points) and Elekta (4.0 points) stood out (Table 5)

An estimate of the culinary properties of potato varieties and a change in them during storage

\begin{tabular}{|c|c|c|c|c|c|c|c|c|c|c|c|c|c|}
\hline \multirow{2}{*}{ Variety } & \multicolumn{6}{|c|}{ Start of storing } & \multicolumn{6}{|c|}{ End of storing } & \multirow{2}{*}{$\begin{array}{l}\text { Loss, } \\
\text { point }\end{array}$} \\
\hline & 1 & 2 & 3 & 4 & 5 & 6 & 1 & 2 & 3 & 4 & 5 & 6 & \\
\hline \multicolumn{14}{|c|}{ Early varieties } \\
\hline Banba & 4.3 & 4.1 & 4.3 & 3.7 & 4.8 & 21.2 & 3.9 & 3.6 & 4.0 & 3.6 & 4.6 & 19.7 & 1.5 \\
\hline Torondo & 3.9 & 4.0 & 4.3 & 3.5 & 4.8 & 20.5 & 3.6 & 3.7 & 4.1 & 3.5 & 4.5 & 19.4 & 1.1 \\
\hline Christina & 3.7 & 4.3 & 4.3 & 4.4 & 4.6 & 21.3 & 3.4 & 4.0 & 4.0 & 4.2 & 4.5 & 20.1 & 1.2 \\
\hline $\begin{array}{l}\text { Average for } \\
\text { group }\end{array}$ & 4.0 & 4.1 & 4.3 & 3.9 & 4.7 & 21.0 & 3.6 & 3.8 & 4.0 & 3.8 & 4.5 & 19.7 & 1.3 \\
\hline \multicolumn{14}{|c|}{ Medium ripening varieties } \\
\hline Savannah & 3.0 & 3.9 & 3.2 & 3.4 & 4.4 & 17.9 & 2.8 & 3.1 & 3.2 & 3.2 & 4.3 & 16.6 & 1.3 \\
\hline Setanta & 4.1 & 5.0 & 4.3 & 4.0 & 4.7 & 22.1 & 3.8 & 4.2 & 4.2 & 3.9 & 4.5 & 20.6 & 1.5 \\
\hline Elekta & 4.0 & 3.3 & 4.2 & 4.2 & 4.6 & 20.3 & 3.7 & 3.2 & 3.9 & 4.0 & 4.2 & 19.0 & 1.3 \\
\hline $\begin{array}{l}\text { Average for } \\
\text { group }\end{array}$ & 4.0 & 4.3 & 4.2 & 4.1 & 4.5 & 21.0 & 3.8 & 3.7 & 4.0 & 3.9 & 4.2 & 19.5 & 1.5 \\
\hline
\end{tabular}

Note: 1 - taste, 2 - resistance to flesh darkening, 3 - mealiness, 4 - water content,

5 - boiling property, 6 - the sum of points

Significant changes in taste appeared at the end of storing. While, when laying on storage, out of 6 examined varieties of potato, 4 varieties were given 4.0 and more points on taste, at the end of storing only the variety Bonda was given 3.9 points. All other varieties received a score of much less than 4.0 points, and Savannah -2.8 points. Most varieties lost their taste properties by $0.2-0.3$ points. This decrease in taste is significant because the initial score was $3.7-4.3$ points.

Our study of the content of free tyrosine in the tubers of potato varieties in the dynamics during storage showed a high degree of dependence of the intensity of potato flesh darkening of the tubers on the content of free tyrosine (Table 6). Thus, the increase in the potato flesh darkening of boiled tubers of the Savannah variety, from 1.9 points to 2.9 points, corresponded to an increase in the content of free tyrosine in the tubers during storage from $0.33 \%$ in dry weight to $0.44 \%$. A similar increase in the content of free tyrosine and potato flesh darkening after cooking was observed in all studied varieties. The degree of potato flesh darkening was adequate in quantitative terms to the increase in the content of free tyrosine.

Table 6

Dependence of the potato flesh darkening on the content of free tyrosine in potato tubers

\begin{tabular}{|c|c|c|c|c|c|c|c|}
\hline \multirow{2}{*}{$\begin{array}{l}\text { Group of } \\
\text { potato } \\
\text { ripeness }\end{array}$} & \multirow[t]{2}{*}{ Variety } & \multicolumn{3}{|c|}{$\begin{array}{l}\text { Free tyrosine con- } \\
\text { tent, mg \% for } \\
\text { the raw mass }\end{array}$} & \multicolumn{3}{|c|}{$\begin{array}{c}\text { Darkening of the } \\
\text { boiled tuber } \\
\text { flesh, point }\end{array}$} \\
\hline & & 1.10 & 15.01 & 11.04 & 1.10 & 15.01 & 11.04 \\
\hline \multirow{4}{*}{$\begin{array}{l}\text { Early- } \\
\text { ripening }\end{array}$} & Banba & 0.28 & 0.34 & 0.43 & 1.8 & 2.0 & 2.4 \\
\hline & Torondo & 0.27 & 0.28 & 0.39 & 1.8 & 2.0 & 2.3 \\
\hline & Christina & 0.21 & 0.27 & 0.29 & 1.0 & 1.4 & 2.0 \\
\hline & $\begin{array}{l}\text { Average } \\
\text { for group }\end{array}$ & 0.25 & 0.30 & 0.37 & 1.53 & 1.8 & 2.23 \\
\hline \multirow{4}{*}{$\begin{array}{l}\text { Medium } \\
\text { ripening }\end{array}$} & Savannah & 0.33 & 0.38 & 0.44 & 1.9 & 2.6 & 2.9 \\
\hline & Setanta & 0.21 & 0.25 & 0.28 & 1.0 & 1.4 & 1.8 \\
\hline & Elekta & 0.28 & 0.32 & 0.37 & 2.1 & 2.4 & 2.8 \\
\hline & $\begin{array}{l}\text { Average } \\
\text { for group }\end{array}$ & 0.27 & 0.31 & 0.36 & 1.5 & 1.95 & 2.35 \\
\hline
\end{tabular}

There was no big difference between the varieties in terms of mealiness, this indicator was given mostly $4.2-4.3$ points, except for Savannah (3.2 points). All varieties at the end of storing reduced their mealiness indicator to some extent, by $0.2-0.3$ points.

The water content of all studied potato varieties ranged, on average, from 3.4 in Savannah to 4.4 points in Elekta. In most varieties, the water content indicator exceeded 4 points; no varieties that are absolutely resistant to wateriness were found. The wateriest varieties when laying on storage were Savannah, Tornado, which received, respectively, 3.4 and 3.5 points. After storing, the water content of potato varieties increased, but not significantly.

The boiling property of all the varieties we studied was very high both when laying on storage and at the end of storing. This is the only indicator that was relatively low for the Savannah variety (4.4 points when laying on storage and 4.3 at the end of storing).

Based on the sum of points according to the indicators that characterize the culinary properties of potato, all varieties at the end of storing did not demonstrate 
sharp differences from each other (19.0-20.6 points), except for the Savannah variety (16.6 points), but all decreased, to some extent, their initial indicators.

It is difficult to establish a comprehensive change in the chemical composition when storing potato tubers of any variety as the chemical components change in different ways.

To compare the comprehensive estimate of preserving the consumer value of potato varieties, the total quality factor was calculated [26].

It was established that the Savannah and Tornado varieties are distinguished on the basis of the set of indicators for the content of basic nutrients after harvesting and after storing. The total quality factor at the end of storing was 0.88 and 0.86 , respectively (Table 7 ).

Total quality coefficient of potato varieties at the end of storing

\begin{tabular}{|c|c|c|c|c|c|c|}
\hline \multirow[b]{2}{*}{ Variety } & \multicolumn{5}{|c|}{ Quality coefficient of some components } & \multirow{2}{*}{$\begin{array}{c}\text { Total } \\
\text { quality } \\
\text { coefficient }\end{array}$} \\
\hline & $\begin{array}{c}\text { Dry } \\
\text { matter }\end{array}$ & Starch & $\begin{array}{l}\text { Total } \\
\text { sugar }\end{array}$ & $\begin{array}{l}\text { Vita- } \\
\text { min C }\end{array}$ & $\begin{array}{c}\text { Raw } \\
\text { protein }\end{array}$ & \\
\hline \multicolumn{7}{|c|}{ Early-ripening } \\
\hline Banba & 0.97 & 0.95 & 0.50 & 0.85 & 0.85 & 0.83 \\
\hline Tornado & 0.90 & 0.92 & 0.70 & 0.84 & 0.91 & 0.86 \\
\hline Christina & 0.95 & 0.90 & 0.33 & 0.76 & 0.94 & 0.78 \\
\hline \multicolumn{7}{|c|}{ Medium ripening } \\
\hline Savannah & 0.96 & 0.95 & 0.82 & 0.75 & 0.95 & 0.88 \\
\hline Setanta & 0.93 & 0.91 & 0.49 & 0.85 & 0.94 & 0.82 \\
\hline Elekta & 0.97 & 0.95 & 0.15 & 0.86 & 0.93 & 0.77 \\
\hline
\end{tabular}

During the storage period, the total content of essential nutrients in the varieties decreased in the range of 12-23\%. The Elekta and Christina varieties significantly reduced their quality only due to the increased sugar content.

In general, over the storage period, all varieties lost their original consumer quality within equal limits.

Thus, according to the set of indicators that characterize the culinary properties of potato, both when laying on storage and at the end of storing, the varieties Banba and Christina should rank first, and, among the medium ripening varieties, the variety Setanta.

Based on the established patterns of changes in the quality of potato tubers, it should be emphasized that potato should be stored at a temperature of $2 \ldots 4^{\circ} \mathrm{C}$ and relative humidity of 85-90\%. Under such conditions, negative changes in product quality are minimized.

5. 3. Correlation links between the culinary properties of potato and the components of chemical composition

Our correlation analysis shows that the overall estimate of the quality of potato tubers after storing depends largely on the organoleptic characteristics (tuber mealiness, taste, and boiling property). The correlation coefficient is $0.918,0.845$, and 0.733 , respectively (Table 8 ).
Table 8 quality indicators of potato tubers

\begin{tabular}{|c|c|c|c|c|c|c|c|c|}
$X_{3}$ & $X_{4}$ & $X_{5}$ & $X_{6}$ & $X_{7}$ & $X_{8}$ & $X_{9}$ & $X_{10}$ & $X_{11}$ \\
\hline- & - & - & - & - & - & - & - & - \\
\hline 1 & - & - & - & - & - & - & - & - \\
\hline-0.727 & 1 & - & - & - & - & - & - & - \\
\hline 0.229 & -0.543 & 1 & - & - & - & - & - & - \\
\hline-0.489 & 0.272 & 0.160 & 1 & - & - & - & - & - \\
\hline-0.326 & 0.872 & -0.561 & 0.190 & 1 & - & - & - & - \\
\hline-0.725 & 0.435 & -0.025 & 0.894 & 0.244 & 1 & - & - & - \\
\hline-0.186 & 0.054 & 0.273 & 0.338 & 0.081 & 0.544 & 1 & - & - \\
\hline-0.678 & 0.460 & -0.220 & 0.870 & 0.261 & 0.834 & -1 & 1 & - \\
\hline-0.622 & 0.616 & -0.120 & 0.844 & 0.567 & 0.917 & 0.579 & 0.733 & 1 \\
\hline
\end{tabular}

The mealiness of potato tubers has a strong direct relation to taste $(r=0.894)$ and an inverse strong relation to sugar content $(r=-0.725)$. The boiling property of tubers depends on the content of sugars and starch $(r=-0.679$ and $r=0.571)$. The resistance to potato flesh darkening - on the content of vitamin $\mathrm{C}(r=0.872)$. The content of starch and raw protein has almost the same effect.

\section{Discussion of results of studying the culinary properties of potato tubers of different varieties}

Sugar is the main indicator that the quality of all types of meals and potato products depends on. Sugars affect the color of the finished product and predetermine the shelf life of varieties as the raw materials for processing throughout the entire storage period. It follows from the data obtained from our experiment that the largest amount of sugars is contained, before and after storing, in potatoes of the early-ripening variety Banda 0.45 and $0.49 \%$, of the medium ripening variety Savannah $-0.42,0.52$, respectively (Table 3 ). Of great technological importance are the processes that occur in tubers when storing at temperatures below $2{ }^{\circ} \mathrm{C}$. Under these conditions, there is an increase in sugar content at low temperatures. It was found that the content of sugars in potato tubers at a storing temperature of $2 \ldots 4^{\circ} \mathrm{C}$ ranged from $0.47 \%$ in the early-ripening tubers to $0.49 \%$ in the medium-ripening ones (Table 3). Reducing the storing temperature to $0{ }^{\circ} \mathrm{C}$ leads to an increase in sugar content to $0.96-1.12 \%$, respectively. Storing at a temperature of $8 \ldots 10{ }^{\circ} \mathrm{C}$ leads to a reduction in sugars to $0.40-0.42 \%$. This is due to the different rates of reactions of carbohydrate exchange: the decomposition of starch to sugars, the conversion of sugars to starch, the oxidation of sugars during respiration. As the storing temperature decreases, the rate of these reactions slows down. Thus, the use of sugar in the process of respiration is reduced by almost three times. A significant accumulation of sugars can lead to the formation of a sweet taste of tubers. According to experiments [27], it was found that with an increase in the storing temperature to $10{ }^{\circ} \mathrm{C}$, the starch resynthesis reaction increases larger than others. It was established that from $2 / 3$ to $3 / 4$ of the sugar 
content is converted into starch, the rest is oxidized during respiration [28].

It is believed that the high sugar content in tubers can become, under certain storing conditions, a favorable substrate for the development of fungal infections [11].

The Tornado and Setenta potato varieties are characterized by the smallest number of them, which makes it possible to recommend these varieties to produce crispy potatoes and French fries. Processing into chips may include freshly harvested tubers of the Tornado variety with a sugar content of $0.4 \%$.

It was found that the storing duration affects the deterioration of taste, smell, potato flesh darkening, and boiling property. It is observed that tubers with darkened flesh have a worse taste (Tables 6, 8).

Our study has found that the taste of tubers has a strong correlation with boiling property and mealiness, respectively $(r=0.87, r=0,89)$. Similar results were obtained when studying the potato variety Lord [29]. When storing, the smell and taste of Lord tubers correlate negatively $(r=-0.887)$ with the structure of the flesh, humidity. The smell of tubers negatively correlates $(r=-0.761)$ with the structure of the flesh, moisture, and taste. The boiling property of tubers correlates $(r=0.87)$ with the structure of the flesh.

This study has shown that the culinary properties of tubers depend on the potato variety and a group of potato ripeness (Table 5). The highest sum of points, 22.1, was given to the medium ripening potato variety Setanta. The early-ripening potatoes received a score of 21.3. The varietal dependence of potato taste and the content of mineral substances in potato is given in paper [30]. Its authors studied 11 Polish varieties of potatoes (Bartek, Beata, Briza, Danusia, Maryna, Morse, Tokay, Triada, Viking, Zebra, Zeus) and three Dutch varieties (Asterix, Redstar, Victoria). It was found that the content of $\mathrm{P}$ and $\mathrm{Cu}$ correlates with organoleptic indicators. But the study was conducted on the basis of two indicators only.

A varietal effect indicates the possibility of using selection methods to create varieties with predefined mineral composition and organoleptic properties.

The variety Setanta was absolutely resistant to darkening, 5 points, when laying on storage. The varieties Christina and Banba should be considered relatively stable (4.34.1 points). The variety Savannah, 3.9 points, cannot be considered resistant to darkening (Table 4). It was found that the potato flesh darkening depends on the content of basic chemical substances (Table 1). The variety Setanta, resistant to darkening, contains $24.1 \%$ of dry matter, $17.1 \%$ of starch sugars, $0.42 \%$, vitamin C $17.3 \mathrm{mg} / 100 \mathrm{~g}$, raw protein $9.9 \%$. In [31], it was found that the potato varieties that are resistant to potato flesh darkening should contain at least $18 \%$ of starch, at least $22 \%$ of dry matter.

Mechanical tissue damage causes the potato flesh darkening of boiled tubers. It is explained by the unilateral process of the oxidation of phenolic compounds, which, in turn, is caused. Mechanical damage can be of various nature: injuries during harvesting, transportation, peeling, due to the lack of oxygen in the internal tissues when potatoes are cooked.

Other researchers have linked the potato flesh darkening to the warming temperature after storing the potatoes. The best values of resistance to darkening in the raw and boiled tubers were provided by air conditioning temperatures:
12 and $16{ }^{\circ} \mathrm{C}$ (Satina, Mozart and Arosa); 8 and $12{ }^{\circ} \mathrm{C}$ (Red Lady); 16 and $20^{\circ} \mathrm{C}$ (Cifra).

The current study has shown that the ratio of starch to protein content ranges from 5.7 for the early varieties of potatoes to 6.2 for the medium-ripening ones.

In the group of early-ripening varieties, a higher ratio of starch content to proteins 6.0 was found in the variety Christina, in the group of medium ripening varieties - Elekta, 6.4. Under such a ratio of starch to protein, the boiling property ranges from 4.7 for the early varieties to 4.5 in the medium ripening ones (Table 3 ).

Other researchers [32] argue that potato has the best culinary properties when the ratio of starch to protein is $12: 16$. With an increase in the starch over protein content by 8 times, tubers do not boil, and, at an increase by 16 times, they crack during cooking in a peel. The content of glutamic and aspartic acids renders a special taste to potatoes. But the study was conducted for a single variety of potato and under artificially created cultivating conditions.

After a comprehensive commodity estimate, which characterizes the quality of potato and determines the total index of the comprehensive indicator for the nutrients contained in potatoes after storing (Table 7), we estimated potato varieties based on a comprehensive indicator of quality, expressed in points. The initial content of essential nutrients when laying on storage is estimated at 5 points. A comprehensive quality indicator characterizes the quality of vegetable produce in total. Currently, it can be used in the canning industry, food companies, where vegetables are stored and processed over a long time. When selling, to establish an estimate of the objective consumer value of the product. When setting the price, a comprehensive quality indicator should also be taken into consideration.

It was found that the studied varieties of potato contain, on average, $78.6 \%$ of water (Table 3 ). Thus, the dry matter content in the range of $21.1-21.6 \%$ at the beginning of storing, $18.7-20.8 \%$ at the end of storing, the losses were insignificant and the potatoes retained turgor at a relative humidity of $90-95 \%$.

Decreased relative humidity leads to the transpiration of water from the tissues and the wilting of tubers. An increase poses a risk of condensation at the surface of the product. Study [33] proved that at a storing temperature of $3 \ldots 4^{\circ} \mathrm{C}$ and relative humidity of $90-95 \%$ the weight loss by potatoes ranged from $3.6 \%$ for the Golubka variety to $5.1 \%$ for the Nevsky variety. Under the conditions of relative humidity of $80-85 \%, 5.0$, and $9.6 \%$, respectively.

The uniformity and stability of temperature and humidity in the bulk of the product are the necessary storing conditions at minimal losses.

Our systematization of the studied potato varieties by purpose has allowed us to note the following recommendations:

- to produce food potatoes, the varieties Savannah and Tornado can be recommended;

- to produce crispy potatoes and dried potato products, the varieties Setanta, Tornado are the most suitable;

- for processing into starch, the varieties Banda and Christina are recommended;

- to prepare a side meal for dietary food, the potato variety Elekta is recommended.

This study can be advanced by investigating the culinary properties of potato depending on the post-harvest processing, potato storing technique and mode. The use of the 
quantitative criteria makes it possible to comprehensively estimate potato preservation, to plan the time of selling it, to monitor the dynamics of quality, to predict preservation.

\section{Conclusions}

1. At a storing temperature of $2 \ldots 4^{\circ} \mathrm{C}$, the yield of marketable products for the early varieties averages $88.22 \pm 1.53 \%$, for the medium ripening varieties $-96.87 \pm 1.09 \%$. Natural weight loss during storage averaged $4.2 \%$ in tubers from all varieties, of which $72.9 \%$ account for moisture evaporation, and $27.1 \%$ - weight loss. In the group of early varieties, weight loss ranged from $4.1 \%$ in the Christina variety to $5.1 \%$ in the Banda variety. Storing temperature $\left(0 \ldots 2{ }^{\circ} \mathrm{C}\right)$ leads to an increase in the natural weight loss to $5.53 \pm 0.2 \%$ in the early-maturing varieties, to $5.21 \pm 0.53 \%$ in the medium ripening ones. The yield of marketable products for the early varieties is, respectively, $87.46 \pm 1.37$ and $89.92 \pm 1.09 \%$.

2 . It has been established that the formation of taste is affected by the content of chemical components. We have determined a difference in chemical composition between the group of potato varieties and within a single group of ripeness. In terms of the content of dry matter, starch, and vitamin $\mathrm{C}$, raw protein, the early group of varieties outperforms the medium ripening ones. A difference in the dry matter content between the varieties reached $8.2 \%$, starch $-7.0 \%$, sugar $-0.05 \%$, vitamin $\mathrm{C}-5.6 \mathrm{mg} / 100 \mathrm{~g}$, raw protein $-1.4 \%$. When storing, there occur changes in nutrient content. The losses of dry matter were in the range of $2.8-5.2 \%$; the content of starch during storage amounted to $7.1 \%$ of its initial content while the increase in sugars was $12.6 \%$. The increase in sugar content is due to the different reaction rates of the carbohydrate complex. The larg- est losses of starch, $9.7 \%$, were observed in the early-ripening varieties. The losses of Vitamin $\mathrm{C}$ by the groups of potato ripeness were in the range of $14.8-34.5 \%$. Depending on the variety, the losses ranged from $14.8 \%$ (variety Elekta) to 34.2 (variety Tornado).

3. The content of quality indicators separately does not give a complete picture of quality in general. It is proposed to characterize the comprehensive content of nutrients by a total index, which is equal to the sum of the partial indices of the culinary properties of potato varieties and changes in them during storage. To compare the comprehensive estimate of the preservation of the consumer value of potato varieties, a comprehensive quality indicator has been determined, which characterizes the quality of products in general. It has been established that the Savannah and Tornado varieties are distinguished according to the set of indicators of the content of basic nutrients after harvesting and after its storage. The total quality coefficient at the end of storing is 0.88 and 0.86 , respectively. According to the set of indicators that characterize the culinary properties of potato, both when laying on storage and at the end of storing, the varieties Banba and Christina rank first, and, among the medium ripening varieties, the variety Setanta.

4. It has been mathematically proven that the overall estimate of the quality of potato tubers depends to a greater extent on the organoleptic parameters (tuber mealiness, taste, and boiling property). The correlation coefficient is $0.918,0.845$, and 0.733 , respectively. The mealiness of potato tubers has a strong direct relation to taste $(r=0.894)$ and an inverse strong relation to the sugar content $(r=-0.725)$. The tuber boiling property depends on the content of sugars and starch $(r=-0.679$ and $r=0.571)$. The resistance to potato flesh darkening - on the content of vitamin C $(r=0.872)$.

References

1. Dinamika proizvodstva kartofelya v mire v 1961-2019 gg. Top-15 stran-proizvoditeley. Available at: https://potatosystem.ru/ dinamika-proizvodstva-kartofelya

2. Navarre, D. A., Goyer, A., Shakya, R. (2009). Nutritional Value of Potatoes. Advances in Potato Chemistry and Technology, 395-424. doi: https://doi.org/10.1016/b978-0-12-374349-7.00014-3

3. McNulty, H., Pentieva, K. (2004). Folate bioavailability. Proceedings of the Nutrition Society, 63 (4), 529-536. doi: https://doi.org/ $10.1079 /$ pns2004383

4. Diretto, G., Al-Babili, S., Tavazza, R., Papacchioli, V., Beyer, P., Giuliano, G. (2007). Metabolic Engineering of Potato Carotenoid Content through Tuber-Specific Overexpression of a Bacterial Mini-Pathway. PLoS ONE, 2 (4), e350. doi: https://doi.org/10.1371/ journal.pone.0000350

5. Ezekiel, R., Singh, N., Sharma, S., Kaur, A. (2013). Beneficial phytochemicals in potato - a review. Food Research International, 50 (2), 487-496. doi: https://doi.org/10.1016/j.foodres.2011.04.025

6. Bovell-Benjamin, A. C. (2007). Sweet Potato: A Review of its Past, Present, and Future Role in Human Nutrition. Advances in Food and Nutrition Research, 1-59. doi: https://doi.org/10.1016/s1043-4526(06)52001-7

7. Van Jaarsveld, P. J., Marais, D. W., Harmse, E., Nestel, P., Rodriguez-Amaya, D. B. (2006). Retention of $\beta$-carotene in boiled, mashed orange-fleshed sweet potato. Journal of Food Composition and Analysis, 19 (4), 321-329. doi: https://doi.org/10.1016/ j.jfca.2004.10.007

8. Kartoplia: pidsumky y prohnozy. Available at: https://agrotimes.ua/article/kartoplya-pidsumky-j-prognozy/

9. Yakist chypsiv ta kartopli fri zakladaietsia shche u poli. Available at: https://propozitsiya.com/ua/yakist-chipsiv-ta-kartopli-frizakladaietsya-shche-u-poli

10. 5 oshibok pri hranenii kartofelya. Available at: https://7dach.ru/Exspert/5-oshibok-pri-hranenii-kartofelya-3860.html

11. Koltunov, V. A., Voitseshyna, N. I., Furdyha, M. M. (2014). Resursnyi potentsial sortymentu kartopli. Kyiv, 323.

12. Shpaar, D., Bykin, A., Dreger, D. (2004). Kartofel'. Vyrashchivanie, uborka, hranenie. Torzhok: OOO “Variant”, 466.

13. Podpriatov, H. I., Davydenko, A. Yu. (2016). Kulinarni vlastyvosti bulb riznykh sortiv kartopli. Zbirnyk naukovykh prats NNTs "Instytut zemlerobstva NAAN", 2, 126-135. 
14. Spear, R. R., Holden, Z. J., Ross, C. F., Weddell, B. J., Pavek, M. J. (2017). Sensory Evaluation of Eleven Baked Russet-type Potato Varieties and Clones. American Journal of Potato Research, 95 (1), 92-100. doi: https://doi.org/10.1007/s12230-017-9607-z

15. Taylor, M. A., McDougall, G. J., Stewart, D. (2007). Potato Flavour and Texture. Potato Biology and Biotechnology, 525-540. doi: https://doi.org/10.1016/b978-044451018-1/50066-x

16. Furdyga, M., Vermenko, Y., Sonets, T. (2017). Consumptive qualities of different potato varieties. Plant varieties studying and protection, 13 (1), 100-106. doi: https://doi.org/10.21498/2518-1017.13.1.2017.97382

17. Kozhushko, N. S., Honcharov, M. D. (2012). Selektsiya sortiv kartopli na yakist. Visnyk Sumskoho natsionalnoho ahrarnoho universytetu. Seriya: Ahronomiya i biolohiya, 9, 140-145.

18. Kozhushko, N. S., Honcharov, M. D. (2000). Tekhnolohichna otsinka kartopli na prydatnist do promyslovoi pererobky. Kartoplianstvo, 30, 51-60.

19. Haase, T., Schüler, C., Haase, N. U., Heß, J. (2007). Suitability of Organic Potatoes for Industrial Processing: Effect of Agronomical Measures on Selected Quality Parameters at Harvest and after Storage. Potato Research, 50 (2), 115-141. doi: https://doi.org/ 10.1007/s11540-007-9033-6

20. Puzik, L. M., Bondariev, A. V. (2015). Tekhnolohiна zberihannia i pererobky kartopli, ovochiv i plodiv. Laboratornyi praktykum. Kharkiv, 141

21. Blenkinsop, R. W., Copp, L. J., Yada, R. Y., Marangoni, A. G. (2002). Changes in Compositional Parameters of Tubers of Potato (Solanum tuberosum) during Low-Temperature Storage and Their Relationship to Chip Processing Quality. Journal of Agricultural and Food Chemistry, 50 (16), 4545-4553. doi: https://doi.org/10.1021/jf0255984

22. Sawicka, B., Kuś, J., Barbaś, P. (2006). Darkening of the pulp of potato tubers in an organic farm and integrated tillage systems. Polish Agricultural Journal, 142, 445-457.

23. Chemeda, A., Bultosa, G., Dechassa, N. (2014). Effect of Variety and Storage on the Tuber Quality of Potatoes Cultivated in the Eastern Highlands of Ethiopia. Science, Technology and Arts Research Journal, 3 (1), 84. doi: https://doi.org/10.4314/star.v3i1.14

24. Ekspertyza sortiv kartopli. Metodyka provedennia ekspertyzy sortiv roslyn kartopli ta hrup ovochevykh, bashtannykh, prianosmakovykh na prydatnist do poshyrennia v Ukraini (2016). Ministerstvo ahrarnoi polityky ta prodovolstva Ukrainy, 5-10. Available at: https://www.sops.gov.ua/uploads/page/5a5f415f5df23.pdf

25. Metodychni rekomendatsiyi shchodo provedennia doslidzhen z kartopleiu (2002). Nemishaieva: UAAN, Instytut kartopliarstva, 182.

26. Puzik, L. M., Koltunov, V. A., Hordienko, I. M., Rozhkov, A. O. (2015). Prohnozuvannia zberezhenosti yakosti plodoovochevoi produktsiyi. Kharkiv, 196.

27. Horodniy, M. M., Melnychuk, S. D., Honchar, O. M. (2006). Prykladna biokhimiya ta upravlinnia yakistiu produktsiyi roslynnytstva. Kyiv: Aristei. 484.

28. Kaur, L., Singh, N., Singh Sodhi, N., Singh Gujral, H. (2002). Some properties of potatoes and their starches I. Cooking, textural and rheological properties of potatoes. Food Chemistry, 79 (2), 177-181. doi: https://doi.org/10.1016/s0308-8146(02)00129-2

29. Krochmal-Marczak, B., Sawicka, B., Kie tyka-Dadasiewicz, A. (2017). Culinary properties of selected potato cultivars in relation to storage. Towaroznawcze Problemy Jako ci, 4 (53), 72-81. Available at: http://yadda.icm.edu.pl/yadda/element/bwmeta1.element. ekon-element-000171499460

30. Flis, B., Zimnoch-Guzowska, E., Mankowski, D. (2012). Correlations among Yield, Taste, Tuber Characteristics and Mineral Contents of Potato Cultivars Grown at Different Growing Conditions. Journal of Agricultural Science, 4 (7). doi: https://doi.org/ $10.5539 /$ jas.v4n7p197

31. Davydenko, A. Y. (2017). Improving elements of technology preparation of potato tubers for selling. SWorld. URL: https:// www.sworld.com.ua/konferbel1/11.pdf

32. Safronovskaya, G. M. (2020). Kartofel' iz probirki - kachestvo i produktivnost'. Available at: https://glavagronom.ru/articles/ Kartofel-iz-probirki--kachestvo-i-produktivnost

33. Pshechenkov, K. A., Zayruk, V. N., Elanskiy, S. N., Mal'tsev, S. V. (2016). Hranenie kartofelya. Moscow, 128. 